\title{
Correction to: 2018 International Cancer Education Conference Late-Breaking Abstracts
}

\section{Jennifer Alluisi ${ }^{1}$}

Published online: 18 July 2019

(C) American Association for Cancer Education 2019

\section{Correction to: J Canc Educ (2017) 32 (Suppl 2):S11-S61} https://doi.org/10.1007/s13187-017-1253-0

The original e-online version of this article unfortunately contained a mistake.

The correct title would be "2018 International Cancer Education Conference Late-Breaking Abstracts".

Publisher's Note Springer Nature remains neutral with regard to jurisdictional claims in published maps and institutional affiliations.

The online version of the original article can be found at https://oi.org/ $10.1007 / \mathrm{s} 13187-017-1253-0$

$\triangle$ Jennifer Alluisi

JAlluisi@aaceonline.com

1 American Association for Cancer Education, Charlottesville, VA, USA 